Disclaimer:

This report was prepared as an account of work sponsored by an agency of the United States Government. Neither the United States Government nor any agency thereof, nor any of their employees, makes any warranty, express or implied, or assumes any legal liability or responsibility for the accuracy, completeness, or usefulness of any information, apparatus, product, or process disclosed, or represents that its use would not infringe privately owned rights. Reference herein to any specific commercial product, process, or service by trade name, trademark, manufacturer, or otherwise does not necessarily constitute or imply its endorsement, recommendation, or favoring by the United States Government or any agency thereof. The views and opinions of authors expressed herein do not necessarily state or reflect those of the United States Government or any agency thereof.

\title{
TITLE: PREPARATION OF NORTHERN MID-CONTINENT PETROLEUM ATLAS
}

Cooperative Agreement No.: DE-FG22-96BC14844

Contractor Name and Address: The University of Kansas Center for Research Inc.

Date of Report: $\quad$ August 28, 1997 (Revised)

Award Date: $\quad$ August 30, 1996

Government Award for Current Fiscal Year: \$250,000

Principal Investigators: $\quad$ Lee C Gerhard (Principal Investigator)

Timothy R. Carr (Program Manager)

W. Lynn Watney

Project Manager: $\quad$ Chandra Nautiyal, Bartlesville Project Office

Reporting Period: $\quad$ January 1, 1997 -- March 31,1997

\section{OBJECTIVES}

As proposed, the second year program will continue and expand upon the Kansas elements of the original program, and provide improved on-line access to the prototype atlas. The second year of the program will result in a prototype digital atlas sufficient to demonstrate the approach and provide a permanent improvement in data access to Kansas operators. The ultimate goal of providing an interactive history-matching interface with a regional data base remains for future development as the program covers more geographic territory and the data base expands. The long-term goal is to expand beyond the prototype atlas to include significant reservoirs representing the major plays in Kansas, Nebraska, South Dakota, North Dakota, the Williston basin 
portion of Montana, the Denver-Julesburg basin of eastern Colorado and southeastern Colorado.

Primary products of the second year prototype atlas will be on-line accessible digital data bases covering two additional petroleum plays in Kansas. Regional databases will be supplemented with geological field studies of selected fields in each play. Digital imagery, digital mapping, relational data queries, and geographical information systems will be integral to the field studies and regional data sets. Data sets will have relational links to provide opportunity for history-matching, feasibility, and risk analysis tests on contemplated exploration and development projects. The flexible "web-like" design of the atlas provides ready access to data, and technology at a variety of scales from regional, to field, to lease, and finally to the individual well bore. The digital structure of the atlas permits the operator to access comprehensive reservoir data and customize the interpretative products (e.g., maps and cross-sections) to their needs. The atlas will be accessible in digital form on-line using a World-Wide-Web browser as the graphical user interface.

Regional data sets and field studies will be free-standing entities that will be made available on-line through the Internet to users as they are completed. Technology transfer activities will be ongoing from the earliest part of this project, providing data information sets to operators prior to the full digital atlas compilation.

\section{SUMMARY OF TECHNICAL PROGRESS}

The Digital Petroleum Atlas (DPA) is accessible through the Kansas Geological Survey HomePage under "Oil and Gas Information" (http://www.kgs.ukans.edu/kgs.html), or directly at http://www.kgs.ukans.edu/DPA/dpaHome.html. The prototype Digital Petroleum Atlas remains one of the most visited pages on the Kansas Geological Survey web site (Current usage statistics can be accessed at the bottom of the Petroleum Research Section HomePage or at http://www.kgs.ukans.edu/PRS/usage/ past stats.html).

The multiple-pay Terry Field in Finney County is being added to the DPA. Terry Field is a 1991 discovery with primary producing zones in the Lansing-Kansas City,

Marmaton Morrow and Mississippian. County scale geologic and geophysical maps for Finney County were generated and are available though the DPA (http://www.kgs.ukans.edu/ DPA/County/finney.html). The well-log and other well information for Terry Field have been collected and are being added, a field study is underway and data is being loaded into blank field pages.

\section{On-line Prototype}

The following changes and additions have occurred to the on-line prototype atlas.

DPA HomePage: http://www.kgs.ukans.edu/DPA/dpaHome.html

On the DPA Homepage (http://www.kgs.ukans.edu/DPA/dpaHome.html), the annual report for the first year of the project has been added. The annual report is interactive and provides an interactive overview of the function and content of the DPA. 


\section{Kansas HomePage: http://www.kgs.ukans.edu/DPA/dpaKansas.html}

Field maps and production data for additional Kansas counties were added to the interactive map. Additional regional maps covering gravity and magnetics were added.

\section{County Pages: various URL's}

County geophysical maps were improved and initial geologic maps for Finney County and links were generated (http://www.kgs.ukans.edu/DPA/ County/finney.html).

\section{Field Pages: various URL's}

Additional information (e.g., completion reports and core descriptions) was added to the Arroyo, Big Bow, Gentzler and Schaben fields.

\section{TECHNOLOGY TRANSFER}

Technology transfer is ongoing through presentations at national and regional meetings and through the use of electronic updates and the on-line availability of the DPA products. Project information and Progress Reports are linked to the Digital Petroleum Atlas HomePage. Presentations will be given at the Powder River Basin Section of SPE on May 14 and at the Annual Meeting of the American Association of Petroleum Geologists on April 9. An extended abstract is being prepared for the annual meeting of the Society of Petroleum Engineers (SPE).

Industry continues to access and use the digital data and technology from the DPA project. The DPA remains one of the most accessed pages on the Kansas Geological Survey web site. Usage as measured by hits averages about 600 hits per day. 